\title{
Et udstrakt selv
}

\section{Unges brug af medicinsk kognitiv forbedring for at trives og præstere bedre under uddannelse}

\section{Jeanett Bjønness}

Center for Rusmiddelforskning, Aarhus Universitet

jb.crf@psy.au.dk

Bjønness, Jeanett (2018). 'Et udstrakt selv: Unges brug af medicinsk kognitiv forbedring for at trives og præstere bedre under uddannelse' i Tidsskrift for Forskning i Sygdom og Samfund, nr. 28, 87-111.

Artiklen undersøger unge studerendes (18-25 år) narrativer om trivsel og håndtering af præstationskrav i forbindelse med at være under uddannelse. Unges brug af receptpligtig medicin til ikke-medicinske formål som at trives eller præstere bedre diskuteres i lyset af et øgende præstations- og effektivitetspres $i$ det danske uddannelsessystem. Analysen viser, at de unge bruger medicin ud fra meget forskellige logikker og forbehold. Nogle unge normaliserer egen brug og ser den som en legitim måde at håndtere oplevet pres på og som en mulighed for at differentiere sig. Andre mener, at de burde kunne klare sig uden. Disse unge fortæller om etiske dilemmaer og om en følelse af at snyde og at bevæge sig væk fra et 'autentisk' selv. Mange unge fortæller om en følelse af utilstrækkelighed og om stor ambivalens over for de samfundsmæssige krav, de oplever. Artiklen diskuterer, hvorvidt den øgende individualisering $i$ samfundet, både når det gælder valg og ansvar, måske kræver for meget af unge under uddannelse. 
An elastic self: Young adult's use of pharmaceutical enhancement to thrive and perform better while in education

The article examines young students' (18-25 years) narratives about their well-being and about how they handle performance requirements while being in education. Their use of prescription medicine for non-medical purposes such as thriving or performing better is discussed in the light of an increasing performance- and efficiency pressure in the Danish education system. The analysis shows that the young students use medicine using very different logics and reservations. Some young people normalize their own use and see it as a legitimate way to handle experienced pressure and as an opportunity to differentiate themselves. Others think they should be able to manage without medicine. These young students talk about ethical dilemmas, and about a sense of cheating, and also, about moving away from an 'authentic' self. Many young people express a sense of insufficiency and great ambivalence about the social demands they are experiencing. The article discusses whether the increasing individualization in society, both in terms of choice and responsibility, may require too much of young people in education.

\section{Introduktion}

Denne artikel undersøger unges narrativer om trivsel og håndtering af præstationskrav i forbindelse med at være under uddannelse. Mere specifikt diskuteres unges brug af receptpligtig medicin til ikke-medicinske formål som at trives eller præstere bedre.

Mange unge oplever et stærkt præstationspres, og de arbejder identitetsmæssigt med at forene personlige værdier og ambitioner med de forventninger, de oplever gennem medier, uddannelsesreformer og sociale netværk. Analysen viser, at når de bruger receptpligtig medicin med henblik på at håndtere de oplevede krav, er det ud fra forskellige logikker og forbehold. Nogle studerende oplever kravene som motiverende og brugen som legitim, mens de fleste oplever kravene som uopnåelige og anser ikke-medicinsk brug af receptpligtig medicin som en etisk og samfundsmæssigt kontroversiel strategi for at komme målene lidt nærmere. Jeg foreslår, at disse forskelle både skal studeres på baggrund af uddannelsesmæssige krav og kontekster og i lyset af de studerendes sociale baggrund og ambitioner. Fremtidig forskning på dette felt kan derfor med fordel inddrage intersektionelle perspektiver for dermed at bidrage til mere nuancerede analyser af studerendes oplevelse af muligheder og begrænsninger i forhold til trivsel og præstation, deres 
farmakologiske strategier, samt de identitetsmæssige dilemmaer sådanne strategier kan medføre.

\section{Baggrund}

Hjernedoping, kognitiv optimering, smart drugs, livsstilsmedicin og kosmetisk neurologi - begreberne er mange for det fænomen, hvor medicin bruges for at forbedre kognitive funktioner som opmærksomhed eller hukommelse hos raske personer (e.g. Arria \& Wish, 2006; Bancroft 2009; Chatterjee 2004; Cakic, 2009; Coveney et al., 2011; Hildt \& Francke, 2013; Rose, 2003).

I løbet af de sidste 20 år er ikke-medicinsk brug af receptpligtig medicin for kognitiv optimering eller forbedring (herefter IMRMK) øget blandt unge. Både forekomst og stigning er specielt blevet dokumenteret blandt college-studerende i USA og andre vestlige lande (Boyd et al., 2009; Forlini \& Racine; 2009, LeClair et al., 2015; Maier \& Schaub, 2015; McCabe et al., 2005, 2014; Petersen, 2015; Rabiner et al., 2009; Teter et al., 2010, 2012; Varga, 2012). Studier estimerer således, at mellem $7 \%$ og $34 \%$ af college-studerende i USA bruger medicin som Adderal ${ }^{\mathrm{TM}}$ og/eller Ritalin $^{\mathrm{TM1}}$ for at forbedre deres akademiske præstationer (Hall et al., 2005; McCabe et al., 2006; Varga, 2012, White et al., 2005; SAMSHA, 2013; LeClair et al., 2015).

Samtidigt er et stigende antal børn, teenagere og unge voksne blevet diagnosticeret og medicinsk behandlet for sygdomme som ADHD, depression og angst (Ford et al., 2014; Hamilton, 2009; Jørgensen, 2012; Roy et al., 2011), og mange forskere ser en sammenhæng mellem øget diagnosticering og tilgængelighed af medicin blandt børn og unge voksne (DeSantis \& Hane, 2010; LeClair et al., 2015; McCabe et al., 2007; Mui et al., 2014) og stigningen i ikke-medicinsk brug blandt unge studerende.

I Europa er forskning i IMRMK temmelig begrænset. Gennem de seneste fem år har enkelte, hovedsageligt survey-baserede, studier (Schelle et al., 2015; Maier et al., 2013; Lengvenyte \& Strumila, 2016; Middendorff et al., 2012; Eickenhorst et al., 2012; Franke et al., 2014) dog vist, at IMRMK også forekommer i Europa. Disse studier indikerer en stigning i IMRMK om end i mindre omfang end i USA.

I Danmark understøtter Djøf's studielivsundersøgelse (2017) denne tendens og viser, at $7 \%$ af universitetsstuderende rapporterer at have brugt receptpligtig medicin for at præstere bedre. Samtidigt konstaterer Møldrup \& Hansen (2006), at begreber som 'livsstilsmedicin' i stigende grad er en del af den offentlige danske diskurs ${ }^{2}$ Overskrifter som 'Pigerne går til psykolog, mens drengene ryger hash' 
(Politiken 12.1.2015), 'Gør dit bedste - eller gå til grunde' (Information 27.4.2015) og 'Optimeret ungdom' (Information 3.5.2017) er almindelige i de danske medier.

Da der mangler kvalitative undersøgelser om IMRMK i Danmark, har vi interviewet 60 studerende om deres brug, med fokus på blandt andet mediernes betydning for hvad unge oplever som legitime strategier i forhold til at fungere og optimere i 'præstationssamfundet'. Medierne etablerer sammenhænge mellem diagnosticering, trivsel og medicinbrug i forbindelse med uddannelse, og der kan for eksempel være en tendens til at 'idealisere eller stigmatisere' bestemte tendenser eller strategier (Williams et al., 2008: 840). Overskrifter som 'Vi ødelægger børn og unge med diagnoser og medicin (BT 11.3.2017) eller 'Frit slag for at dope sig til eksamen' (DR nyheder 18.5.2012), er eksempler på normative udsagn, som de unge aktivt fortolker og bruger.

Den aktuelle diskurs omkring fænomenet IMRMK er anderledes end tidligere diskurser om unge og illegale rusmidler, der ofte fokuserede på bestemte subkulturelle minoritetsgrupper af unge, som brugte heroin (fx Agar, 1973; Preble \& Casey, 1969), kokain/crack (fx Decorte, 2000; Briggs, 2012; Bourgois, 1995) eller marihuana (fx Becker, 1953; Hathaway et al., 2011; Sandberg \& Pedersen, 2010). Selv om IMRMK er ulovligt og af flere forskere anses som havende en høj risiko for misbrug og afhængighed (McCabe \& Boyd 2012:10), knyttes IMRMK nemlig ikke i samme grad til afhængighed, kriminalitet og dødelighed som 'traditionelt' illegalt stofbrug blandt marginaliserede og mere synlige unge (Hunt \& Barker 2001). Præstationsfremmende brug problematiseres snarere ved at diskutere etiske dilemmaer omkring retfærdighed og snyd, det naturlige og det kemiske samt det autentiske og kunstige (Chatterjee, 2009; Coveney et al., 2011; Dees, 2007; Farah et al., 2004; Forlini \& Racine, 2009; Hildt \& Francke, 2012; Loe \& Cuttino, 2008; Maslen et al., 2014; Nagel 2010; Petersen et al., 2014; Parens,1998). Denne forskel kan muligvis forklares med, at IMRMK overvejende ses blandt unge i uddannelsessystemet - majoriteten (Hunt \& Barker 2001), og at man som lovgivere og politikere er usikre på, hvordan man skal forholde sig til disse nye grupper og praksisser. En usikkerhed som kan spores i den måde, hvorpå Det Etiske Råd i 2010 indskrev sig i diskussionen omkring kognitiv optimering ved netop at fokusere på etik og retfærdighed:

"Er medicinsk optimering et relativt uproblematisk gode i nutidens samfund, og er det blot én blandt mange måder at blive bedre på? Eller er medicinsk optimering en etisk betænkelig udvikling, fx for retfxrdigheden $i$ samfundet, eller for 
vores opfattelse af hvad der er 'xgte' menneskelige præstationer?" (Det Etiske Råd 2010:5)

Rådet ser en individualisering af kulturen og hævder, at det felt, inden for hvilket individer kan betragte sig selv som 'normale', indskrænkes. Ydermere beskrives en udvikling, hvor opfattelsen af 'sygdom' ændres, og farmakologisk modifikation af tanke, humør og opførsel er blevet mere almindeligt og accepteret - normaliseret (se også Bancroft 2009; Burri \& Dumit 2007; Jørgensen 2012) - samt en bekymring for, at "det for flere og flere bliver stadig mere presserende at medicinere sig for at leve op til omgivelsernes forventninger og krav" (2010:47). Det er den udvikling, forskere som Svend Brinkmann (2010) betegner som en medikalisering af samfundet ${ }^{3}$ - en patologisering af almenmenneskelige tilstande, og at medicinske perspektiver nu anvendes på områder, som tidligere ikke er blevet anskuet som medicinske (Burri \& Dumit, 2007). Brinkmann er kritisk over for denne udvikling, mens andre forskere, som Thomas Søbirk Petersen (2017), er mere positive over for medicinens potentiale.

Mens medikalisering i Brinkmanns optik fortrinsvis betyder (problematisk) øget medicinering af 'normaltilstande', bruger Nicolas Rose snarere begrebet som et startpunkt for en analyse af koblinger mellem subjektivt håb og utilfredshed og det, som medicinen lover (2003:702). Der er tale om komplicerede processer og et skift fra "a clinical gaze" (Foucault, 1975) til et "molecular gaze" (Rose, 2007), som har omfattende betydning for vore livsformer, og for hvem vi har mulighed til at se os selv som (ibid., se også Clarke \& Shim, 2011).

Coveney et al. (2011) finder således begrebet 'farmaceutikalisering' mere brugbart end 'medikalisering', da dette begreb mere præcist betegner den proces, hvor menneskelig erfaring gøres til genstand for farmaceutisk intervention. En intervention som dernæst kan analyseres med fokus på forskellige aspekter som motiver, biologisk påvirkning, legitimitet, kommercielle interesser og så videre. (ibid: 387), men som ikke som udgangspunkt bygger på noget normativt. ${ }^{4}$

I det følgende vil jeg etablere en analytisk ramme for at undersøge farmaceutikaliseringsprocesser blandt danske studerende med fokus på deres individuelle motiver og legitimeringsstrategier i lyset af de samfundsmæssige krav, de oplever. 


\title{
Analytisk ramme
}

"Since at least the 18th century in developed countries, medicine played a constitutive part in 'making up people' (...) The history of medicine has thus been bound up with the history of the different ways in which human beings have tried to make ourselves better than we are" (Nicolas Rose, 2007:700).

Som vist er forskningen om IMRMK overvejende survey-baseret. Der er således behov for at udvikle analytiske begreber, som kan sætte fokus på kvalitative sammenhænge mellem væsentlige træk ved det senmoderne vestlige samfund (herunder individualisering og konkurrence) og individers oplevede muligheder for at være det 'selv' - den 'type' individ, som de føler, deres omgivelser kræver (Brinkmann, 2010; Ehrenberg, 2010; Petersen, 2016; Rose, 2003; Willig, 2005).

De fleste unge studerende i vor undersøgelse kobler deres brug af medicinsk kognitiv forbedring til det, de betegner som 'præstationspres', og forstår eget brug i lyset af et samfundsmæssigt og uddannelsesmæssigt krav om at levere gode præstationer. Et eksempel på det er Allan (25), som har en ADHD-diagnose, men bruger sin medicin anderledes end foreskrevet til kognitiv forbedring. Han siger:

\begin{abstract}
"Diagnoser eksisterer i kraft af det samfund, der stiller den (...) ADHD eller $A D D$, det eksisterer vel ikke foruden ideen om, at du skal sidde ned i otte timer og læse bøger, altså så... altså på den måde så forbedrer det mig i den sfære, hvor det er forventet af mig, men i de sfærer, hoor det ikke er relevant at præstere pa de punkter, er det ikke særlig gavnligt (...) det siger mere om, hoilke forventninger der er til folk, og hoilke strukturer der er, end det reelt siger noget om, hoem de mennesker er."
\end{abstract}

Allan peger altså netop på relationen, på spændet, mellem individuel praksis og oplevede præstationskrav, og hans narrativ er et eksempel på, hvordan normative forståelser, som de unge ser for eksempel i fremdriftsreformen og i mediernes opslag, aktivt bruges og fortolkes. Et andet eksempel er Hanna (23), som er meget optaget af mediernes idealbilleder, og som oplever, at "de forbilleder, piger får, er meget ens, og de klarer sig alle sammen godt".

I analyseprocessen viste begrebet 'utilstrækkelighedens patologi' ('the pathology of insufficiency', Ehrenberg 2010) sig brugbart som et analytisk udgangspunkt for at udforske både de studerendes strategier for at optimere deres præstationer og de måder, hvorpå IMRMK legitimeres i deres narrativer. Begrebet indfanger 
netop relationen mellem individet og sociale normer og dermed et af de væsentlige temaer i de unges narrativer om deres brug af 'optimeringsteknologier' (Rose, 2003): En følelse af at strække sig mod mål, som både er stærke og udefinerbare.

Det, at de unge ofte taler om IMRMK som et nødvendigt modtræk til angsten for at mislykkes eller falde helt ud, gør, at jeg ser paralleller til Ehrenbergs (2010) betragtning om, at 'moderne depression' kan være en konsekvens af oplevet utilstrækkelighed i sociale kontekster, hvor selvrealisering og succes er forventet af det autonome individ. Anders Petersen (2016) mener også, at depressionsepidemien må ses på baggrund af, at præstation har fået status af at være idealet for det gode liv. Mange af de unge fortæller således om venner eller bekendte, der 'går ned' på grund af presset, og at der ikke er tid til at være ineffektiv. Louise (21) oplever at mestre kravene, men udtrykker dog stadig en usikkerhed: "Det gik jo godt til de der eksamener. Men den blev bare ved med at være i baghovedet; hvad hois det nu ikke gør?"

Vi ser altså, at litteraturen peger på nye sammenhænge mellem selvet og definerende samfundstræk. 'Det normale' defineres på nye måder, og individer føler sig i tiltagende grad nødsaget til forholde sig til kravet om at motivere, optimere og evaluere sig selv for at være i stand til at øge effektivitet og produktivitet (se også Skagestad \& Madsen, 2015; Willig, 2005). Det er sådanne sammenhænge, som skal udforskes i det følgende, hvor jeg analyserer de unges narrativer om, og legitimering af, deres IMRMK i lyset af de skitserede temaer, herunder en holdningsmæssigt noget mudret dansk diskurs, hvor kognitiv optimering altså både betragtes som doping og pligt. Der vil være et særligt fokus på de unges forståelse og beskrivelse af brug af Ritalin ${ }^{\mathrm{TM}}$ og betablokkere ${ }^{5}$ som teknologier brugt for at møde egne, andres og samfundsmæssige forventninger om at være et aktivt og kompetent individ. Det vil fremgå, at de unge på forskellige måder erfarer at leve i et 'optionssamfund' (Willig, 2005), og at de betragter IMRMK som en hjælp til at kunne være og præsentere det aktive, ansvarlige og succesrige selv, som de føler, blandt andet uddannelsesinstitutionen (herunder fremdriftsreformen), medier og forældre forventer af dem.

\section{Metode og informanter}

Artiklen bygger på kvalitative interviews med 60 unge voksne mellem 18 og 25 år, som på interviewtidspunktet er studerende ved forskellige danske uddannelsesinstitutioner. ${ }^{6+7}$ Rekruttering foregik via en facebookside, foldere og postere med 
teksten: "Tager du noget - for at trives eller præstere bedre, mens du uddanner dig?" Ydermere præsenterede vi projektet på 10 forskellige uddannelsesinstitutioner, og en række studievejledere hjalp med at formidle kontakt til unge.

Tre interviewere foretog semi-strukturerede interviews (1 1/2-3 timers varighed) mellem 1.9.2015 og 1.7.2016. De fleste interviews fandt sted i Center for Rusmiddelforsknings lokaler, men der blev også foretaget interviews på uddannelsesstederne og i de unges hjem.

Vi stillede de unge generelle spørgsmål om social baggrund, hverdag, trivsel og fremtidsdrømme, samt mere specifikke spørgsmål om studieliv, ambitioner og mulig stress og bekymring. Der var specielt fokus på, hvorvidt og hvordan medicin og/eller illegale stoffer indgik i de studerendes overvejelser om og strategier for at trives og præstere. Vi var særligt opmærksomme på, hvordan de unges narrativer spejler de forskellige og til dels meget politiserede og moralske tendenser i den offentlige diskurs, herunder i medierne og i forskernes egen tilgang (Hunt \& Barker 2001). ${ }^{8}$

Lidt mere end halvdelen af de interviewede havde brugt præstationsfremmende medicin som Ritalin ${ }^{\mathrm{TM}}$ (flest mænd) eller betablokkere (kun kvinder, i forbindelse med eksamensangst). ${ }^{9}$ Når vi tager brug af betablokkere med i gruppen af præstationsfremmende medicin, er det, fordi mange af informanterne reflekterer over et sådant brug på lignende måder som over brug af kognitiv optimering med for eksempel Ritalin ${ }^{\mathrm{TM}}$. Selv om en række unge forstår deres brug af alkohol, illegale rusmidler og angst/depressionsmedicin som en form for præstationsfremmere, er disse stoffer dog ikke taget med her, da der i første omgang ønskes en diskussion af det, de unge selv kategoriserer som medicinsk kognitiv optimering eller forbedring. ${ }^{10}$

Konteksten for analysen er en læsning af nyere litteratur omkring kognitiv optimering i forbindelse med uddannelse samt udvalgte sociologiske teorier omkring det senmoderne selv.

\section{Fund og analyse}

Fælles for de studerende er, at de oplever et stort og tiltagende pres i forhold til deres uddannelse, og at de tager medicinen for at imødekomme dette pres og præstere bedre. De har mange metaforer for, hvad det at tage medicin for kognitiv forbedring gør for dem; "Man bliver strømlinet", "den fjerner emhættestøj", "jeg bliver puppet-master omkring mit hoved". De beskriver det også som "en rollator- 
ting", "en krykke", "at skubbe til sig selv", "et boost" og så videre. Deres narrativer om brug, samt hvilken rolle IMRMK har i deres strategier for at håndtere presset, er dog meget forskellige. ${ }^{11}$

Den følgende analyse er baseret på de respondenter, som bruger receptpligtig medicin for at præstere bedre på deres uddannelse, og som ikke forbinder en sådan brug med rus. Der er 1) ikke- diagnosticerede unge, der bruger eksempelvis Ritalin $^{\mathrm{TM}}$, som de køber eller får af bekendte, for optimering, og 2) unge, der har en diagnose (ofte ADHD) og bruger deres medicin ikke-medicinsk for optimering, samt 3) Ikke-diagnosticerede unge, der bruger betablokkere for at dæmpe eksamensangst. ${ }^{12}$ Analysen fokuserer indledningsvis på de unge, som betragter IMRMK som uproblematisk, og derefter på dem, der er mere ambivalente og enten er kritiske over for oplevet samfundsmæssigt pres eller optaget af etiske aspekter og diskussioner omkring snyd og doping.

\section{Uproblematisk brug og ønsket om at blive bedst}

De unge i denne gruppe læser på universitetsuddannelser med høje adgangskrav og får rigtig gode karakterer på deres studie. Målet er at blive en af de bedste i verden til sit fag. For dem er centralstimulerende substanser som Ritalin ${ }^{\mathrm{TM}}$ en legitim måde at blive bedre til at fokusere og præstere på. Axel (21), som er udiagnosticeret Ritalinbruger, betragter folk, som bruger Ritalin" ${ }^{\mathrm{TM}}$, som "ambitiøse mennesker", og han forbinder IMRMK med "folk, som virkelig gerne vil noget". IMRMK modstilles af Axel til svaghed og også til for eksempel hashbrug, som anses som "ikke akademisk". Ritalin ${ }^{\mathrm{TM}}$, som er det mest udbredte stof, bliver af disse unge nærmest udelukkende beskrevet som et "præstationsstof" og som et "akademisk stof". Axel siger:

"Jeg tager det ikke, for at det skal være sundt. Men jeg ryger jo heller ikke hash. Jeg kender nogen, der ryger hash. De bliver sløve og langsomme, og jeg vil gerne være hurtig og hurtigst. Det går lidt i modsat retning, ikke?"

Philip (21), som heller ikke er diagnosticeret, har det på samme måde:

"Jeg har venner, der tager kokain, og det er et stort tabu $i$ mit hoved, at du tager kokain for eksempel (...) I mit hoved er det meget ulovligt. Du putter noget $i$ din næse, du ikke har styr på. Som kommer fra Columbia, som kommer hertil 
og bliver blandet op, og det er ligesom et mørkt miljø, jeg ikke er interesseret $i$ at være en del af."

Vi kan altså se, at det er vigtigt for disse unge at italesætte deres stofbrug som en anden type fænomen end illegalt stofbrug, og de er heller ikke interesserede $i$ at tale om eventuelle bivirkninger. Philip og Axel understreger, at de har kontrol over deres IMRMK, og de har ikke de store forbehold eller etiske overvejelser om eget brug. De tager det, de synes, der virker og som hjælper på deres koncentration og præstation. Axel siger:

"Akademisk doping - ja, det kan da godt være. Men altså, man må jo differentiere sig. Så er jeg sgu ligeglad, altså. Jeg ser det ikke som snyd, ikke som direkte snyd. Fordi alle, der gerne vil have det, kan godt få det jo. Så det ser jeg ikke, jeg ser det ikke som snyd til en eksamen-altså overhovedet ikke (...) det gør bare, at du er mere fokuseret. Det er ligesom kaffe. Du bliver mere frisk. Bare en lidt mere ekstrem form (...) Jeg vil bare gerne finde min grænse. Hvor meget kan jeg presse mig selv?"

Axel og Philip oplever pres, men de præsenterer det snarere som en motivationsfaktor end som noget, de føler sig utilstrækkelige i forhold til. De fokuserer altså nærmest udelukkende på de muligheder, som medicinen giver (Petersen, 2017).

For Louise (21), en af de få kvinder i vores materiale, som rapporterer at bruge Ritalin $^{\mathrm{TM}}$ for at præstere bedre, er presset mindre lystbetonet. Hun fik en ADHDdiagnose som 16-årig, og har også diagnosen anoreksi. Louise betragter IMRMK som nødvendig for at indfri de oplevede krav:

"Jeg prover hele tiden enormt meget at leve op til nogle forventninger, enten nogle som jeg selv finder på eller nogle, som ligger implicit. Det er egentlig ikke fordi, at der nogensinde er nogen, der har sagt til mig "nå, men du bør gøre så og så", men det ligger der bare."

I Louises narrativ fremstilles kravene som stærke, men samtidigt som svære at lokalisere og uhåndgribelige - "de ligger der bare". Hun forestiller sig en præstationsskala, som hun synes, det er en selvfølge at prøve at nå op i:

"Du skal helst klare det så godt som muligt. Hvis du ender med at blive læge eller advokat eller direktør for en eller anden virksomhed. Så på en eller anden 
arbitrær skala, så har du egentlig klaret dig meget godt. Altså så tror jeg, at det prøver man selvfølgelig at leve op til..."

Men præstation bliver også noget selvforstærkende, og det er svært at stå af:

"På et eller andet tidspunkt, så begynder omverdenen også bare at forvente, at så er det det, du gør, så er det naturligt for dig. Så folk kigger ikke to gange på, hvis du fär et tolvtal. Men hvis du til gengxld fär syv eller ti, så er det godt nok, wow, så begynder folk at kommentere på det. Og det har man heller ikke lyst til."

Når jeg senere i interviewet med Louise spørger hende, om hun betragter sit Ritalinbrug som selvmedicinering, svarer hun, at hun ikke tror, hun har ADHD, men at Ritalinen hjælper hende til at fungere bedre og "skubbe til sig selv", og at hun er ligeglad med, hvorvidt man kalder det "medicinering" eller "enhancement".

Eksemplerne ovenfor peger på forskellige måder på sammenhænge mellem diagnoser, normalisering af kognitiv optimering og oplevede krav om at præstere i uddannelsessystemet. Både Axel, Philip og Louise spejler sig i det perfekte. De vil være den bedste, og medicinen er en oplevet legitim strategi for at blive det (se også DeSantis \& Hane, 2010). Louise mener, som for eksempel Thomas Søbirk Petersen (2017), at IMRMK er en form for doping, men samtidigt at "hvis det fører til, at vi får nogle rigtig dygtige forskere eller kirurger, eller hvad det nu måtte være, så er det måske ikke så slemt". Målet helliger så at sige midlet for disse unge, og de oplever kravene som mulige at indfri ved hjælp af medicinen.

De fleste fortæller dog, som vi skal se i det følgende, en ganske anden historie. Disse unge er også vant til at få gode karakterer, men sammenlignet med den første gruppe læser de på uddannelser med lavere adgangskvotienter. Deres narrativer spejler også fortællinger, ikke mindst mediebårne, om perfektion og gode præstationer, men for denne gruppe unge medfører normen om selv-realisering flere identitetsmæssige refleksioner. Målet er ikke nødvendigvis at blive bedst, men snarere at præstere så godt som muligt, og opfyldelsen af denne ambition med IMRMK er for mange knyttet til stor ambivalens. En del af dem giver udtryk for, at de går på kompromis med personlige holdninger for at leve op til nogle samfundsmæssige præstationskrav, som de er kritiske overfor. Andre er optagede af de etiske implikationer af IMRMK. Fælles er en oplevelse af at strække sig mod noget, som ofte føles både usundt, utydeligt og uopnåeligt (Ehrenberg, 2010; Willig, 2005). 


\title{
Ambivalent brug: Fokus på det samfundsmæssige pres
}

Behovet for at være i kontrol både med selvpræsentation og præstation er, som i den første gruppe, også tydeligt i disse unges narrativer. Mange siger, at de tager medicin 'for en sikkerheds skyld'. De taler dog samtidigt om, at de gerne ville undvære medicinen, og at de har en følelse af at stræbe imod noget usundt.

Allan (25) er en ambitiøs studerende, som fik en ADHD-diagnose som 12-årig ${ }^{13}$. Han bruger sin Ritalin ${ }^{\mathrm{TM}}$ anderledes end foreskrevet, og siger:

\begin{abstract}
"Man bliver meget skarpere, man bliver meget mere... man bliver mere strømlinet på en eller anden måde, så altså, $i$ stedet for at man tænker $i$ øst og vest, så har man mere en stil, som man bare kan følge, elaborere på og blive inspireret af (...) man bliver mere fokuseret."
\end{abstract}

For Allan er brug af Ritalin ${ }^{\mathrm{TM}}$, som det også var for Axel og Philip, tæt knyttet til præstation og skarpt stillet op mod rekreativt brug. Han siger, at stoffet gør ham vågen og skarp, og det medvirker til, at "det hele flyder mindre" i uddannelsessammenhæng. I modsætning til den første gruppe, som vi så legitimere deres brug ved at differentiere sig fra illegale stofbrugere og individuel mangel på kontrol, er Allan og de andre i denne gruppe dog mere optaget af samfundsmæssige forhold og normer, som det kan være svært leve op til, og de ser brugen som en ambivalent individuel respons på en 'social patologi' (Ehrenberg, 2010). Samtidigt legitimerer de ofte deres brug ved at sidestille det med mere accepterede former for optimering som kaffe eller motionsløb.

Allan ser en sammenhæng mellem store præstationskrav og egen diagnose og medicinbrug, og han betragter ADHD som en 'kulturel lidelse', som ville kunne undgås i et mere rummeligt uddannelsessystem. Han er således ambivalent over for den ADHD-diagnose, han fik i folkeskolen. Ganske rigtigt rykkede hans karakterer fra 4 til 10, men samtidigt mener han, at hvis talent blev forstået lidt bredere, ville han ikke have haft behov for medicin:

"Hvor Ritalin så har hjulpet mig meget $i$ folkeskolen og gymnasiet til ligesom at få gode karakterer og til ligesom at lykkes akademisk, og det kan man sige, det er jo en god ting, fordi tydeligvis så har jeg nogle talenter, som ogsa kunne komme til udtryk i skolesystemet. På den anden side så er det lidt en skam, at de talenter skal udtrykkes så ensidigt, at man er nodt til at skulle tage piller, for at det kommer til udtryk, så det er sådan lidt dobbelt ikke..." 
Allan mener, at man som samfund går glip af noget kompetence og kreativitet ved at bruge medicin til at "lykkes akademisk".

Anton (23) har, i modsætning til Allan, ikke nogen diagnose, men bruger også Ritalin $^{\mathrm{TM}}$ for at kunne koncentrere sig bedre. Som Allan er Anton meget kritisk overfor, at "man har et præstationssamfund, der presser folk til at gøre ting, de ikke føler, de vil gøre". Han betragter presset for at præstere som det egentlige problem, og han er kritisk overfor, at fritiden "bliver brugt på at gøre kroppen klar til at arbejde igen og lave den der præstation". Når han alligevel bruger Ritalin ${ }^{\mathrm{TM}}$ til trods for, at han forbinder medicinen til et usundt pres, legitimerer han det på følgende måde:

"Ritalin vil jeg se på linje med, at man løber nogle ture om dagen for at holde sin krop og sin hjerne klar, hoilket også er en form for præstationsfremmende. Jeg ville bare se det som et andet værktøj, men at alle løber hele tiden, det synes jeg virker meget mere usundt (...) Om man så tager Ritalin eller ej, så synes jeg, det er et problem, at folk føler sig utilstrækkelige og ikke føler sig værdsat i forhold til den præstation, de laver i en grad, så de bliver nødt til at brænde sig selv ned."

Jeg ser et paradoks i, at Anton forklarer sit IMRMK med (uønskede) samfundsmæssige og strukturelle krav, samtidig som han også søger at normalisere det ved at sammenligne med overdreven træning.

Allans og Antons narrativer illustrerer altså, at både individuel sygdom, men også individuelle strategier i forhold til oplevet pres under uddannelse, skal forstås i lyset af specifikke samfundsmæssige forhold (Ehrenberg, 2010; Rose, 2003). De er ikke bekymret over for eget brug, som de føler, de har kontrol over. Bekymringen gælder snarere de samfundsmæssige tendenser, som de oplever, at deres IMRMK spejler og reproducerer. En af disse tendenser er en oplevelse af en række krav i en konkurrence- og præstationskultur, som føles nærmest umulige at indfri. Anton taler om, at han prøver at leve op til kravene, samtidig med at han stiller sig kritisk til dem:

"Den der utilstrækkelighed der virker til, at man hele tiden har små mål, som man ikke når i mål med, for et nyt mål er sat, og man ikke har en fornemmelse af, hvor kom jeg fra, fordi målstregen hele tiden rykker sig. Så hvor er begyndelsespunktet overhovedet? Så det bliver sådan flydende, og det kan jeg bare mærke, at det er jeg vildt dårlig til, så det prøver jeg sådan aktivt at sætte mig uden for. 
Hvilket så er svært, når ens talenter ligger rent akademisk, og jeg ikke bare kan gå ud i en skov og hugge noget brænde."

En følelse af, at målene er udefinerede og bevægelige, gør altså, at disse unge føler sig utilstrækkelige (Ehrenberg 2010), og som det Willig (2010) kalder 'tilpasningsdygtige nomader'. Flere giver udtryk for oplevelse af, at kravene er strømlinede, i den forstand at det hele tiden handler om at effektivisere og maksimere egen tid og indsats, men at målet samtidigt kan synes uklart. For eksempel blev Anton, da han kom fra en lille by i Vestjylland til København for at læse, overvældet af det store fokus på "CV-snak og selfbranding og sådan noget". Selv om han, som vi også så ovenfor, er kritisk over for det, han beskriver som et (for) konkurrencepræget uddannelsessystem, kan han dog ikke rigtig se sig ud af det. Det hænger sammen med, at han ud over selve uddannelsen også føler, der er mange andre ting, han bør mestre:

\begin{abstract}
"Nu her næste semester (...) der skal jeg arbejde, så at jeg kan tage ud at rejse efter jul. Inden min kandidat, for så tror jeg også, at jeg rent faktisk kunne sige: nå, nu har jeg taget en storre rejse, nu kan jeg rent faktisk have en fluebensagtig fornemmelse omkring, at det er gjort - og nu kan jeg komme videre."
\end{abstract}

Denne 'fluebensagtige' fornemmelse af, at der er en række krav, som skal opfyldes, før man kan komme videre, er gennemgående i de unges narrativer. Og ligeså gennemgående er ambivalensen over for egne strategier, som Anton udtrykker det i følgende citat:

"Jeg vil også gerne have, at min rejse bliver en del af min selviscenesættelse på et eller andet tidspunkt, selvom jeg synes, at det er irriterende, at man skal tænke på den måde."

Denne selviscenesættelse foregår blandt andet på Facebook, som han betegner som en "irriterende vellykkethedsudstilling". Ritalinbrug bliver således en forudsætning for en højst ambivalent selvkonstruktion, som Anton betragter som både "ulækker", "destruktiv" og "usmagelig". Han er, som vi kan se, meget ambivalent over for egne valg og identitetsmæssigt temmelig udfordret i sin hverdag. Måske befinder han sig i grænselandet til den 'moderne depression', som Ehrenberg (2010) ser som en konsekvens af oplevet utilstrækkelighed i sociale kontekster, hvor selvrealisering og succes er forventet af det autonome individ. 
Det samme spørgsmål kan man stille til Taibs (24) narrativ. Taib (24) er ikke diagnosticeret, men bruger de Ritalin ${ }^{\mathrm{TM}}$-lignende præparater Concerta og Medikinet for at kunne arbejde mere. Han ser en tydelig sammenhæng mellem effektivisering, stress, depression og IMRMK og er kritisk over for udviklingen. Taib føler, at han bliver nødt til at arbejde "mere end alle andre", fordi hans familie har dårlig økonomi. Medicinen gør det muligt for ham at indfri egne ambitioner, men når han betegner sit medicinbrug som "en krykke, man burde kunne leve uden", tolker jeg det som et forsøg på at tage ansvar for aktivt at leve sine drømme (Rose, 2003:54) - og således en strategi for at undgå stagnation og passivitet og muligvis depression (Ehrenberg, 2010).

Presset for at være aktiv, vælgende og 'iværksætteragtig' er således en måde, de studerende styres på, men det er også en måde, de styrer sig selv på - noget de oplever som et (ambivalent) imperativ, fordi at afvigelse fra normen erfares som problematisk og ekskluderende.

Hanna (23) er også en af dem, som er bange for at falde igennem, og som har været det siden gymnasietiden. Hun er u-diagnosticeret journaliststuderende og bruger betablokkere til eksamen, selv om hun tror, hun vil klare sig ok uden. Hanna har nemlig en idé om, at enten så lykkes man, eller så er man ingen:

"Altså, der er jo sådan en eller anden tanke i det her system om, at hvis man ikke får de bedste karakterer, så kan du ikke komme ind på de bedste uddannelser. Så kan du ikke få det bedste job, og så kan du ikke, og så bor du i en papkasse. Altså, fordi hois du får en firer i kemi, så bor du i en papkasse lige om lidt, ikke. Der er den der stige, du kan komme op ad, eller også så falder du helt ned."

Vi kan se, at hun har temmelig dystopiske tanker om, hvad der vil ske, hvis man ikke honorerer de oplevede krav, samtidigt med at hun er reflekteret omkring egen praksis:

"Ja. Jeg har indset enormt meget, men der er en eller anden del af min hjerne, der ikke helt er med på den endnu (...) Altså, det er jo stadigvæk en jagt på at være perfekt, ikke? Ja. der er jo, det er jo bare stadigvæk, hvad er tilladt? Hvad må jeg? Er jeg stadigvæk, passer jeg stadigvæk ind? Er jeg mærkelig nu?"

Opsummerende kan vi altså se. at de unge her gennemgående føler sig utilstrækkelige - og at de kæmper for at opnå noget, som, måske, er uden for rækkevidde, 
hvis de ikke bruger medicin. De tør ikke tage chancen at lade være. Det at mislykkes uddannelsesmæssigt er identitetsmæssigt skræmmende, for hvem er man så?

Den sidste gruppe af de ambivalente unge er optagede af de etiske aspekter omkring deres brug - hvad er 'normalt', og hvad er overdreven perfektion - hvor går grænsen mellem det rene og det kunstige, og hvornår er brug at betragte som snyd og dermed 'akademisk doping'?

\section{Ambivalent brug: Fokus på etiske dilemmaer}

Når ambivalensen handler om etiske aspekter ved brug, stiller de unge sig de samme spørgsmål, som vi så Det Etiske Råd gøre: Er kognitiv optimering en naturlig udvikling, eller er det snyd? Olivia (23), som er u-diagnosticeret og tager betablokkere til eksamen, synes som de fleste andre, at hun burde klare sig uden:

\footnotetext{
"Holdningsmæssigt har jeg altid tænkt, at det burde ikke være nødvendigt, og jeg tænker, at jeg burde kunne klare det uden-altså du burde ikke gå ind og blive så nervøs for sådan en ting, at du er nødt til tage hjælpemidler for at kunne klare det - tage medikamenter for at kunne komme igennem det. Jeg tænker, det er sådan en simpel ting $i$ livet at skulle gå op til en eksamen - altså i princippet - hoad sker der, hois du dumper?"
}

Denne slags usikkerhed, omkring hvad der er acceptabelt (se også Willig, 2005), går igen for de fleste unge, når de overvejer deres IMRMK. De føler sig utilstrækkelige, og at medicinen gør det lidt lettere at leve op til kravene og at komme igennem - men samtidigt føler de også, at de burde klare sig uden - at de snyder. Hanna siger om sin brug af betablokkere:

"Det er jo lidt snyd, ikke. Altså havde jeg været cyklist, havde det jo været doping. For jeg har jo medstuderende, som ikke har en sød lage, som har lyst til at udskrive dem betablokkere, og som bare har svært ved at trække vejret. Og på den anden side så ser jeg det også sådan lidt som sådan en, 'nå men altså de fleste af dem trækker jo vejret fint, så jeg prover bare på at komme op på niveau med dem', ikke."

For Hanna er der altså en udjævningslogik, en mild form for snyd, som hun betragter som væsentligt anderledes end det at "optimere sin hjerne" med for eksempel Ritalin ${ }^{\mathrm{TM}}$, som i hendes optik "virkelig er at snyde". Men selv om hun er 
reflekteret omkring, at hun ikke vil "det der perfektionsræs", tør hun ikke slippe de betablokkere, som hun føler sikrer, at hun kan være med.

Også i diskussionen om snyd relaterer de unge deres brug til social og samfundsmæssig kontekst. Teodor (23) har ingen diagnose, men bruger det Ritalinlignende stof Medikinet for at kunne koncentrere sig. For ham handler det også om en form for retfærdighed:

"Det kan man godt kalde for en doping, men jeg synes ikke, det er snyd. Altså $ø h m$, så er det også snyd, at der er nogle mennesker, hvis forældre har flere penge og kan købe en lejlighed til dem. Det er også præstationsfremmende midler. Så penge er også præstationsfremmende midler."

Som Teodor har Hanna også fokus på socioøkonomisk baggrund. Hun overvejer, om det kan forsvares at bruge medicin, når man eksempelvis er nødt til at arbejde om natten for at have økonomi til at studere. Men på den anden side mener hun, at hvis man har brug for medicin for at klare sit studie, så burde man måske ikke være der:

"Hvis du læser jura eller sådan et eller andet, og du skal læse så mange timer om ugen, at det er fysisk umuligt for dig rent faktisk at gøre det, og du tager Ritalin. Så er du, altså så er jura nok bare ikke studiet for dig, eller også så er der noget helt, helt galt med jura."

Opsummerende kan vi altså se, at de unge her taler ind i en retfærdigheds- eller lighedslogik, og søger at legitimere deres brug ud fra en idé om, at det er med til at udjævne strukturelle forskelle. Vi kan se, at deres praksis afspejler nogle normative forventninger om præstation, og at de samtidig forholder sig til, hvad der er etisk acceptable strategier for at imødekomme presset. Interessant er det således, at deres praksis repræsenterer den beskrevne normalisering (Burri \& Dumit, 2007; Rose, 2007) af farmaceutikalisering af individuelle problemer, men at deres personlige holdning samtidigt er, at det ville være bedre uden.

\section{Konklusion og perspektivering}

Denne artikel har udforsket, hvordan unge oplever pres for at præstere og være succesrig som både en motivationsfaktor og som fyldt med dilemmaer. Artiklen 
har belyst, hvordan de unge, med forskellige begrundelser og forbehold beskriver IMRMK som en mulig strategi for at håndtere det pres, de oplever. Et særligt fokus har været på de dilemmaer og den usikkerhed, mange unge oplever, når det er svært at forene de personlige værdier med samfundsmæssige og etiske fordringer. Deres selvfølelse er tæt bundet op på samfundsmæssige ideer om akademisk succes, og det ikke at kunne leve op til forventningerne beskrives som skræmmende. Samtidig betragter mange af de unge IMRMK som 'snyd', særlig hvis der ikke er sociale eller personlige grunde til, at man har brug for hjælp til at optimere eller forbedre sin præstation. Derimod er de ikke særligt optagede af, at deres brug er ulovligt.

Afslutningsvis vil jeg diskutere, hvordan forskningen konstruktivt kan engagere sig i diskussioner om unges optimerings- og forbedringsstrategier i et normativt landskab i hurtig forandring.

En række forskere og medier har rejst bekymring for, at IMRMK er i stigning blandt unge, samt tendensen til at sådanne optimeringsteknologier normaliseres i den vestlige verden (Burri \& Dumit, 2007; Det Etiske Råd 2010; Quintero \& Nichter, 2011). Andre er mere optagede af, at diskussioner omkring kognitiv optimering og dennes betydning for menneskers hverdagsliv har været for snæver (Rose, 2007), og at de både har fokuseret for lidt på følelsesmæssige og kropslige aspekter (Vrecko, 2013) og på begrebsmæssig præcisering (Coveney et al., 2011).

$\mathrm{Vi}$ har set, at mange unge i denne undersøgelse er i tvivl om, hvad de faktisk kan tillade sig; om de 'snyder', men også mere overordnet om hvilket samfund deres medicinbrug er medskaber af. De unge italesætter sig selv som strategiske, men også som ambivalente og usikre, når de aktivt prøver at konstruere et vellykket selv i en kontekst med høje akademiske idealer. De er 'the Ritalin generation' (Loe \& Cuttino 2008:306, se også Petersen, 2015), som har receptpligtig medicin i deres 'tool kit' for at sikre akademisk succes, men som samtidigt aktivt konfronterer det at lade sig forme af medicin (Karp, 2006) og at lade deres 'sande selv' modificeres eller maskeres af medicin (se også Rose, 2007).

De unge engagerer sig således i en praksis, som de både opfatter som potentielt stigmatiserende og som en nødvendig komponent $\mathrm{i}$ at konstruere det ønskede selv. Deres bestræbelser på at fortælle en sammenhængende og konsistent historie om sig selv og egne strategier afslører en stor ambivalens. Man kan således spørge sig, om de unge, når den offentlige diskurs, herunder medierne, indeholder så mange modstridende ytringer, efterlades i det Forlini \& Racine (2009) kalder 'et etisk tomrum', hvor det kan være svært at finde gode løsninger. De tager medicin og strækker sig på den måde for at præstere og være i kontrol, men medicinen er 
for mange med til at give en følelse af at miste både kontrol og i yderste konsekvens sig selv. Dette er paradokset, de unge føler sig fanget i: De gør det, de tror, der forventes af dem, men er i tvivl, om midlet - medicinen - kan accepteres, og hvad brugen gør dem til.

Ydermere synes det egentlige mål for anstrengelserne at være uklart for mange af de unge. At forbedre eller optimere er jo en uendelig proces, og flere oplever, at målet hele tiden flytter sig.

Herværende analyse har søgt at vise, at ideen om individets ansvar for at være aktiv, succesrig og selvrealiserende tilsyneladende medvirker til en følelse af utilstrækkelighed for mange studerende. Selvet er i en vis forstand både midlet og produktet (Bell, 2000), og når kravene opleves som uoverskuelige, bliver IMRMK en måde at nå lidt mere og således komme lidt nærmere på den ønskede identitet. Prisen, mange unge fortæller om, er dog, at de oplever at miste lidt af deres 'naturlige selv', og at IMRMK kan udgøre en sprække mellem en 'autentisk' eller 'ideel' identitet og den, de rent faktisk formår at leve op til. Man kan måske sige, at de oplever, at deres selv bliver (for) 'udstrakt' og dermed sårbart. I lyset af blandt andet Roses og Willigs samtidsdiagnose, at akademisk succes i en neo-liberal tid opleves af de studerende som nærmest udelukkende deres eget ansvar, samtidig med at de beskriver et stort og altomfattende pres, kan man diskutere, hvorvidt samtidens individualisering af værdisystemer er kommet til at kræve for meget af den enkelte (Nagel, 2010).

Det har været en pointe i denne artikel, at unge oplever og reagerer forskelligt på pres. Både tilbøjeligheden til at bruge IMRMK og overvejelserne over sådant brug varierer både med køn og social baggrund. Denne artikel har ikke fokuseret eksplicit på intersektionelle sammenhænge, men der er brug for kvalitative intersektionelle analyser om, hvordan brug af IMRMK varierer med livsfase, situation, klasse, køn og etnicitet (Rose 2007:700). Ydermere er der brug for opmærksomhed og refleksion fra forskere, politikere og meningsdannere både på ændringer i kontekster for brug og på den mening, brugere selv tillægger deres brug i lyset af sådanne ændringer.

\section{Noter}

1: Disse produkter indeholder det aktive stof Methylphenidat og gives som oftest til ADHD- eller ADD-diagnosticerede.

2: Margit Anne Petersens forskning om brug af receptpligtige stimulanser blandt studerende i New York har fået noget mediemæssig opmærksomhed i Danmark. Opmærk- 
somhed har også Thomas Søbirk Petersens (2017) arbejde omkring doping fået. Kongstad (2008) diskuterer etiske problemer ved "hjernedoping" i sit speciale, og Nielsen et al. (2003) har diskuteret, hvordan receptpligtig medicin associerer med socio-økonomisk position i Danmark.

3: Medikalisering betyder i Brinkmanns optik øget medicinering, mens i den internationale diskussion om begrebet ses det mere som en flersidet proces, hvor man blandt andet taler om, at lægers indflydelse bliver mindre (Coveney et al 2011).

4: Nogle er for eksempel optaget af, at lægers autoritet, som et resultat af internettets tiltagende betydning som informationskilde og marked, bliver mindre (Furedi, 2006), mens andre fokuserer på medicinalindustriens indflydelse (Busfield, 2006).

5: Betablokkere er blodtryksnedsættende medicin.

6: Projektet er finansieret af Helsefonden og Center for Rusmiddelforskning.

7: De læser fx på HF, sygeplejerskoler, universiteter og produktionsskoler. Enkelte informanter er mellem 25 og 30 år.

8: I den kommende artikel "Uddannelsespres set fra flere vinkler - Vejlederes og studerendes oplevelser af fremdriftsreformen", vil dette tema være i centrum.

9: Der er væsentlige og interessante kønsforskelle, både når det gælder oplevelse af pres og holdninger til medicinbrug. Disse vil blive behandlet i andre publikationer.

10: Brug af disse stoffer under uddannelse vil blive behandlet i kommende publikationer. For eksempel så Maria sit brug af teen Ayahuasca således som den omvendte bestræbelse af Ritalinbrug. Det er en måde at optimere sin indlæring på, men også en måde at kunne træde ud af forventningerne.

11: Fælles for de fleste interviewede er dog, at de i meget lille grad er optaget af, at det er ulovligt at bruge receptpligtig medicin ikke-medicinsk. Mange af dem er ikke enggang klar over, at det er ulovligt.

12: Andre bruger melatonin for at kunne sove, hash eller alkohol for at slappe af/koble fra (det vi ofte kalder selvmedicinering) eller bevidsthedsudvidende stoffer som ayahuasca for selvudvikling og inspiration. Der er dog i denne gruppe en højere andel, som karakteriserer deres brug som rusorienteret eller som selvmedicinering.

13: Når der refereres til diagnose, er det kun ADHD- og ADD-diagnoser, som nævnes. Andre diagnoser, som $\mathrm{fx}$ depression og angst, tages ikke med i denne sammenhæng.

\section{Referencer}

Agar, M. (1973). Ripping and running: A formal ethnography of urban heroin addicts: Academic Press.

Arria, A. \& and Wish, E. (2006) Nonmedical Use of Prescription Stimulants among Students. Pediatric Annals 35(8): 565-571. https://doi.org/10.3928/0090-4481-20060801-09.

Arria, A.M., Caldeira, K.M., O'Grady, K.E., Vincent, K.B., Johnson, E.O., \& Wish, E.D. (2008). Nonmedical use of prescription stimulants among college students: Assosiations with attention-deficit-hyperactivity-disorder and polydrug use. Pharmacotherapy, 28, 156-169. https://doi.org/10.1592/phco.28.2.156.

Bancroft, A. (2009). Drugs, Intoxication and Society. Chichester: John Wiley and Sons. 
Becker, H. (1963). Outsiders: Studies in the Sociology of Deviance. New York: Free Press of Glencoe.

Bell, S. E. (2000). »Experiencing Illness in/and Narrative.« In C. E. Bird, P. Conrad \& A. M. Fremont (Eds.), Handbook of Medical Sociology (pp. 184-199). Upper Saddle River, NJ: Prentice Hall.

Berlingske Tidende (2017) 'Vi ødelægger børn og unge med diagnoser og medicin' Set 11.3. 18.

Bourgois, P. (1995). In Search Of Respect: Selling Crack in El Barrio. Cambridge: Cambridge University Press.

Bourne, James. (2011). From bad character to BPD: The medicalisation of 'personality disorder'. In M. e. a. Rapley (Ed.), De-medicalizing misery. Hundsmill, Ballingstoke, Hampshire: Palgrave Macmillan. https://doi.org/10.1057/9780230342507.0010.

Boyd, C. J., McCabe, E.E., \& Teter, C.J. (2006). Medical and nonmedical use of prescription pain medication by youth in the Detroit-area public school district. Drug Alcohol Depend, 81, 37-45. https://doi.org/10.1016/j.drugalcdep.2005.05.017.

Boyd, C. J., McCabe, E.E. \& Cranford, J.A. (2007). Prescription drug abuse and diversion among adolescents in a southeast Michigan school district. Arch Adolenc Pediatr Med, 161, 276-281. https://doi.org/10.1001/archpedi.161.3.276.

Boyd, Carol J. et.al. (2009). Adolecents' Nonmedical Use of Prescription Medications and Other Problem Behaviors. Journal of Adolescent Health, 45, 543-550. https://doi. org/10.1016/j.jadohealth.2009.03.023.

Briggs, D. (2012). Crack Cocaine Users: High Society and Low life in South London. Abington: Oxon Routledge

Brinkmann, S. (Ed.) (2010). Det diagnosticerede liv. Sygdom uden grænser. Århus: Forlaget Klim.

Burri, R.V. \& Dumit, J. (eds) (2007). Biomedicine as Culture: Instrumental Practices, Technoscientific Knowledge and New Modes of Life. New York: Routledge.

Busfield, J. (2006). Pills, Power, People: Sociological Understandings of the Pharmaceutical Industry. BSA Publications 40(2), 297-314. https://doi.org/10.1177/0038038506062034.

Cakic, V. (2009) Smart drugs for cognitive enhancement; ethical and pragmatic consideration in the era of cosmetic neurology. Journal of Medical Ethics, 35(10):611-615. https://doi. org/10.1136/jme.2009.030882.

Chatterjee, A. (2004). Cosmetic neurology. The controversy over enhancing movement, mentation and mood. Neutrology 63: 968-974.

Chatterjee, A. (2009). Is it acceptable for people to take methylphenidate to enhance performance? British Medical Journal 338 (b1956).

Clarke, A., \& Shim, J. (2011). Medicalisation and Biomedicalisation Revisted: Technoscience and Transformations of Health, Illness and American Medicine. I: Pescosolido, B.A, et al. (red.) Handbook of the Socioogy of Health, Illness and Healing. A blueprint for the 21th century. New York: Springer.

Coveney, C. (2011). Cognitive Enhancement? Exploring Modafinil use in Social Context. Sociological Reflections on the Neurosciences. Advances in Medical Sociology, 13, 203228. https://doi.org/10.1108/S1057-6290(2011)0000013013.

Coveney, C. (2012). Cognitive enhancement? Exploring modafinil use in social context. In M. Pickersgill \& I. Van Keulen (Eds.), Sociological reflections on the neuroscience (pp. 203228): Emerald Group Publishing Limited. 
Coveney, C, Gabe, J. \& Williams, S. (2011). The sociology of cognitive enhancement: Medicalisation and beyond. Health Sociology Review, 20(4), 381-393. https://doi.org/10.5172/ hesr.2011.20.4.381.

Coveney, C. M, Nerlich, B. \& Martin. P. (2009). Modafinil in the media: Metaphors, medicalisation and the body. Social science $\mathcal{E}$ Medicine, 68, 487-495. https://doi.org/10.1016/j. socscimed.2008.11.016.

Davis-Berman, Jennifer L. \& Pestello, Frances G. (2005). The medicated self. Studies in Symbolic Interactionism, 28, 283-308. https://doi.org/10.1016/S0163-2396(04)28022-X.

Decorte, T. (2000). The Taming of Cocaine: Cocaine Use in European and American Cities. Brussels: VUB Press.

Dees, R. (2007). Better Brains, Better Selves? The Ethics of Neuroenhancement. Kennedy Institute og Ethics Journal 17(4):371-395. https://doi.org/10.1353/ken.2008.0001.

Djøf (2014) Djøf's studielivsundersøgelse. https://www.djoef.dk/ /media/documents/djoef/s/ studielivsunders-oe-gelse-2014.ashx?la=da

DeSantis, A. D., \& Hane, A.C. (2010). »Adderal is Definitely Not a Drug«: Justifications for the Illegal Use of ADHD Stimulants. Substance use and misuse, 45, 31-46. https://doi. org/10.3109/10826080902858334.

DR Nyheder (2012) 'Frit slag for at dope sig til eksamen'. Set 18.5.18

Ehrenberg, A. (2010) The Weariness of the self. Diagnosing the History of Depression in Contemporary Age. Quebec: McGill-Queens University Press.

Eickenhorst, Patrick, Vitzthum, M.S, Klapp, B.F., Groneberg, D,\& Mache, S. (2012). Neuroenhancement Among German University Students: Motives, Expectations, and Relationships with Psychoactive Lifestyle Drugs. Journal of Psychoactive Drugs, 44(5), 418477. https://doi.org/10.1080/02791072.2012.736845.

ESPAD. (2007). Alcohol and Drug Use Among European 17-18 Year Old Students.

Farah, M., Illes, J., Cook-DEgan, R., Gardner, H., Kandel, E. King, P. \& Wolpe, P.R. (2004). Neurocognitive enhancement: What can we do and what should we do? Neture Reviews Newroscience 5:421-425. https://doi.org/10.1038/nrn1390.

Ford, J.A., \& Arrastia, M.C. (2008). Pill-poppers and dopers: A comparison of non-medical prescription drug use and illicit/street drug use among college students. Addictive Behaviours, 33, 934-941. https://doi.org/10.1016/j.addbeh.2008.02.016.

Forlini, C., \& Racine, E. (2009). Disagreement with implications: diverging discourses on the ethics of non-medical use of methylphenidate for performance enhancement. BMC Medical Ethics, 10(9), 1-13. https://doi.org/10.1186/1472-6939-10-9.

Foucault, M. (1975). Discipline and Punish. The birth of the prison. London: Penguin.

Franke, A.G, Papenburg, C, Schotten, E, Reiner, P.B. \& Lieb, K. (2014). Attitudes towards prescribing cognitive enhancers among primary care physicians in Germany. BMC Family Practice, 15(3) https://doi.org/10.1186/1471-2296-15-3.

Greely (2010). Enhancing brains. What are we afraid of? Cerebrum, Jul-Aug; 2010: 14.

Hall, K.M., Irwin, M.E., Bowman, K.A., Frankenberger, W., \& Jewett, D.C. (2005). Illicit Use of Prescribed Stimulants. Medication Among College Students. Journal of American College Health, 53 (4), 167-174. https://doi.org/10.3200/JACH.53.4.167-174.

Hamilton, Gloria J. (2009). Prescription drug abuse. Psychology in the Schools, 46(9), 89828898.https://doi.org/10.1002/pits.20429. 
Hathaway, A.D., Comeau, N.C., \& Erickson, P.G. (2011). Cannabis Normalization and Stigma: Contemporary practices of moral regulation. Criminology and Criminal Justice, 11(5), 451-469. https://doi.org/10.1177/1748895811415345.

Hildt, E. \& Francke, A.G. (2013)Cognitive Enhancement. An Interdisciplinay perspective. Dordrecht Heidelberg New York London: Springer. https://doi.org/10.1007/978-94-0076253-4.

Hildt, E., Lieb, K., \& Francke, A.G. (2014). Life context of pharmacological academic performance enhancement among university students - a qualitative approach. BMC Med Ethics, 15(23).https://doi.org/10.1186/1472-6939-15-23.

Hunt, G. \& Barker J.C. (2001) Socio-cultural anthropology and alcohol and drug research: towards a unified theory. Social Science \& Medicine 53, pp 165-188. https://doi.org/10.1016/ S0277-9536(00)00329-4.

Information (2015) 'Gør dit bedste, eller gå til grunde'. Set 24.7.18.

Information (2017) 'Optimeret ungdom' Set 3.5.18.

Juengst, E.T. (1998) What does enhancement mean? I: Parens, E. (red.) Enhancing human traits: ethical and social implications. Georgetown Univeristy Press, Wahington, pp 29-47.

Jørgensen, C.R. (2012). Danmark på briksen? Et psykologisk perspektiv på Danmark og danskerne $i$ det senmoderne. København: Hans Reitzels Forlag.

Karp, D.A. (2006). Is It Me or My Meds? Living with Antidepressants. Cambridge, MA: Harward University Press. https://doi.org/10.4159/9780674039339.

Kongsholm, N.C.H (2008) Den udmærkede, men dopede præstation? Non-liberale etiske problemer ved »hjernedoping « Københavns Universitet. Kandidatspeciale.

LeClair, A., Kelly, B.C., Pawson, M., B.E., Wells, \& J.T., Parons. (2015). Motiations for prescription drug misuse amongyoung adults: Considering social and developmental contexts. Drugs, Education, Prevention and Policy, Early online 1-9. https://doi.org/10.3109 /09687637.2015.1030355.

Lengvenyte, A. \& Strumila, R. (2016) Do medical students use cognitive enhancers to study? Prevalence and correlates from Lithuanian medical student sample. European Psychiatry. Vol 33, Supplement. March. P.304. https://doi.org/10.1016/j.eurpsy.2016.01.1041.

Loe, M., \& Cuttino, L. (2008). Grappling with the Medicated Self: The Case of ADHD College Students. Symbolic Interaction, 31(3), 304-322. https://doi.org/10.1525/si.2008.31.3.303.

Maier, M. , \& Schaub, M. (2015). The use of prescription Drugs and drugs for abuse for neuroenhancemnet in Europe: Not widespread, but a reality. European Pshychologist, 20(3), 155-166. https://doi.org/10.1027/1016-9040/a000228.

Maier, M. J. , Liechti, M. E., Herzig, F., \& Schaub, M. P. (2013). To Dope or Not to Dope: Neuroenhancement with Prescription Drugs and Drugs of Abuse among Swiss University Students. Plos one. 8(11), 1-10. https://doi.org/10.1371/journal.pone.0077967.

Maslen, H., Faulmüller, N., \& Savulescu, J. (2014) Pharmacological cognitive nenhancement - hoe neuroscientific research could advance ethical debate. Neuroscience 8(107):1-12.

McCabe, S.E, Brady T.West, Christian J. Teter, Carol J. Boyd. (2005). Non-medical use of prescription stimulants among US college students: prevalence and corelates from a national survey. Addiction, 100(1), 96-106. https://doi.org/10.1111/j.1360-0443.2005.00944.x.

McCabe, S.E. , Boyd, C.J., \& Teter, C.J. (2006). Medical Use, Illicit use and Diversion of Abusable Prescription Drugs. Journal of American College Health, 54(5), 269-278. https://doi. org/10.3200/JACH.54.5.269-278. 
McCabe, S.E. , Carol J. Boyd \& Amy Young. (2007). Medical and Nonmedical Use of Prescription Drugs among Secondary School Students. Journal of Adolescent Health, 40, 7683. https://doi.org/10.1016/j.jadohealth.2006.07.016.

McCabe, S.E., \& Boyd, S.J. (2012). Does motives matter? Nonmedical Use of Prescription The Prevention Researcher, 19(10-13).

McCabe, S.E., West, B.T., Teter, C.J., \& Boyd, C.J. (2014). Trends in medical use, diversion, and nonmedical use of prescription medications among college students from 2003 to 2013: Connecting the dots. Addictive Behaviours, 39, 1176-1182. https://doi.org/10.1016/j. addbeh.2014.03.008.

Middendorf, E., Poskovsky, J., \& Isserstedt, W. (2012). Formen der Stresskompensation und Leistungssteigerung bei Studierenden. Hannover: HIS Hochshul-Informations-System $\mathrm{GmbH}$.

Mui, H.Z, Sales, P. and Murphy, S. (2014). Everybody's Doing it: Initiation to Prescription Drug Misuse. Journal of Drug Issues, 44(3), 236-253. https://doi.org/10.1177/0022042613497935.

Møldrup, C. (2001). Ethical, Social and Legal Implications of Pharmacogenomics: A Critical Review. Community Genet, 4, 204-214. https://doi.org/10.1159/000064194.

Møldrup, C., \& Hansen, R. R. (2006). Public acceptance of drug use for non-disease conditions. Current medical research and opinion, 22(4), 775-780. https://doi. org/10.1185/030079906X100258.

Nagel, S.K. (2010). Too much of a good thing? Enhancement and the burden of self-determination. Neuroehics 3:109-119. https://doi.org/10.1007/s12152-010-9072-6.

Nielsen, M.W., Hansen, E.H., \& Rasmussen N.K. (2003) Prescription and non-prescription medicine use in Denmark: association with socio-economic position. Eur J Clin Pharmacol 59 pp 677-684. https://doi.org/10.1007/s00228-003-0678-z.

Parens, E. (1998) Enhancing human traits: ethical and social implications. Georgetown Univeristy Press, Wahington, pp 29-47.

Petersen, M.A. (2015). Governing Ambibuities. The use of prescription stimulants for enhancement among university students in New York City. (Ph.d.), University of Copenhagen, Copenhagen.

Petersen, A. (2016). Præstationssamfundet. København: Hans Reitzels forlag.

Petersen, M.A. , Nørgaard, L.S., \& Traulsen, J.M. (2014). Going to the doctor with enhancement in mind - An ethnographic study of university students' use of prescription stimulants and their moral ambivalence. Drugs, Drugs Educ Prev Pol, Early Online, 1-7.

Petersen, T.S. (2017). Vi bør ikke afvise brugen af hjernedoping. Videnskab.dk. 4. maj 2017.

Politiken (2015) 'Pigerne går til psykolog mens drengene ryger hash'. Set 12.1.18.

Preble, E. \& Casey, J.J. (1969). Taking care of business - the heroin user's life on the street. The International Journal of the Addiction, 4(1), 1-24. https://doi.org/10.3109/10826086909061998.

Quintero, G. \& Nichter, M. (2011). Generation RX: Anthropological Research on Pharmaceutical Enhancement, Lifestyle Regulation, Self-Medication and Recreational Drug Use. In M. E. Singer, P.I. (Ed.), A Companion to Medical Anthropology: Wiley.

Rabiner, D.L. , Anastopoulos, A.D., Costello, J.E., Hoyle, R.H., \& Swartzwelder, S.H. (2019). Prediction of nonmedical ADHD Medication Use by College Students. Journal of Attention Disorders, 13(2), 144-153. https://doi.org/10.1177/1087054708320414.

Rose, N. (2003). Neurochemical selves. Society(Nov/dec), 46-59. https://doi.org/10.1007/ BF02688204. 
Rose, N. (2007). Beyond medicalisation. The Lancet. 369 (9562) 700-702. https://doi.org/10.1016/ S0140-6736(07)60319-5.

Rose, N. (2009). Livets politik. Biomedicin, magt og subjektivitet $i$ det 21. århundrede: Dansk Psykologisk Forlag.

Roy, E., Aruda, N., \& Bourgois P. (2011). The growing popularity of Prescription Opioid Injection in Downtown Montréal: New challenges for harm reduction. Substance use and misuse, 46, 1142-1150. https://doi.org/10.3109/10826084.2011.552932.

SAMSHA. (2013). Results from the 2012 National Survey on Drug Use and Health: Summary of national findings Rockville, MD: Substance Use and Mental Health Services Administration.

Sandberg, S. \& Pedersen, W. (2010). Cannabiskultur. Oslo: Universitetsforlaget.

Schelle, K.J., Olthof, B.M.J., Reintjes, W., Bundt., Gusman-Vermeer, J. \& van Mil A.C.C.M: (2015). A survey of substance use for cognitive enhancement by universityu students in the Netherlands. Front. Syst. Neurosci., February 17.

Teter, C. J., LaGrange, K., Cranford J.A., \& Boyd C.J. (2010). Prevalence and Motives for Illicit Use of Prescription Stimulants in an Undergraduate Student Sample Journal of American College Health, 53(6), 253-262.

Teter, C. J. , McCabe, S.E., LaGrange, M.S.W.K., Cranford, J.A., \& Boyd, C.J. (2012). Illicit Use of Specific Prescription Stimulants Among College Students: Prevalence, Motives, and Routes of Administration. Phamocotherapy. The journal of Human Pharmacology and Drug Therapy, 26(10), 1501-1510. https://doi.org/10.1592/phco.26.10.1501.

The Danish Council on Ethics (Det etiske råd). (2010). Medicinsk optimering. Etiske overrvejelser og anbefalinger. København. Rosendahls: Det etiske Råd.

Varga, M. D. (2012). Adderall Abuse on College Campuses: A Comprehensive Literature Review. Journal of Evidence-Based Social Work, 9(3), 293-313. https://doi.org/10.1080/1543 3714.2010.525402.

Vrecko, S. (2013). Just how Cognitive is »Cognitive Enhancement«? On the significance of Emotions in University Students' Experiences with Study Drugs. AJOB Neuroscience, 4(1), 4-12. https://doi.org/10.1080/21507740.2012.740141.

Weil, A. T. (1972). The Natural Mind. Boston: Houghton Mifflin

White, B.P., Becker-Blease, K. A., \& Grace-Bishop, K. (2006). Stimulant Medication Use, Misuse, and Abuse in an Undergraduate and Graduate Student Sample. Journal of American College Health, 54(5), 261-268. https://doi.org/10.3200/JACH.54.5.261-268.

Williams, S.J. Seale, C. Boden, S. Lowe, P., and Steinberg D.L. (2008) Waking up to sleepiness: Modafinil, the media and the pharmaceuticalisation of everyday/night life. Sociology og health and Illness 30(6) pp839-855. https://doi.org/10.1111/j.1467-9566.2008.01084.x.

Willig, R. (2005) Selvrealiseringsoptioner - vor tids fordring om anerkendelse. I: Willig, R. \& M. Østergaard: Sociale Patologier. København: Hans Retitzel. 